\title{
Additional information on the reproductive biology and development of the clausilial apparatus in Pontophaedusa funiculum (Mousson, 1856) (Gastropoda, Pulmonata, Clausiliidae, Phaedusinae)
}

\author{
BARna PÁlL-Gergely \\ Department of General and Applied Ecology, University of Pécs, Ifjúság útja 6, H-7624 Pécs, Hungary, \\ e-mail: pallgergely2@gmail.com
}

PÁll-Gergely B., 2010: Additional information on the reproductive biology and development of the clausilial apparatus in Pontophaedusa funiculum (Mousson, 1856) (Gastropoda, Pulmonata, Clausiliidae, Phaedusinae) - Malacologica Bohemoslovaca, 9: 1-4. Online serial at $<$ http://mollusca.sav.sk $>$ 15-February-2010.

\begin{abstract}
The present paper gives additional information on the reproductive biology and describes the development of the clausilial apparatus (CA) of the clausiliid land snail Pontophaedusa funiculum (Mousson, 1856). There are only minor differences between the CA formation of clausiliid species known from this point of view (Albinaria, Herilla, Pontophaedusa, Vestia). The present species copulates by shell-mounting like other clausiliids, which was mistakenly described differently in our earlier paper. The position of the eggs inside the vagina is illustrated. The eggs hatched synchronously. Egg cannibalism occured sometimes among juveniles and adults as well. In most cases, the eggs which were visible through the translucent shells were laid at once. The numbers of laid eggs largely varied among parental individuals. The egg-laying strategy of Pontophaedusa is discussed. The life span of Pontophaedusa may be longer than 7 years.
\end{abstract}

Key words: Clausiliidae, Pontophaedusa funiculum, breeding habit, reproductive biology, clausilial apparatus

\section{Introduction}

In our earlier paper we published some observations on the breeding habits, shell development, decollation, and reproductive anatomy of the clausiliid land snail Pontophaedusa funiculum (Mousson, 1856) (PÁll-Gergely \& NémEth 2008). However, some questions remain to be resolved in the life history of Pontophaedusa. Similar traits have been described in Polish clausiliids by Maltz \& SulikowsKaDROZD (2008).

The development of the clausilial apparatus (=CA) in Albinaria (N-type CA) and Isabellaria (G-type CA) was studied by GitTenberger (2000), whereas EdLauer (1941) observed the CA formation (N-type) of Herilla bosniensis (L. Pfeiffer, 1868), and Sulikowska-Drozd (2009) of Vestia gulo (E.A. Bielz, 1859). Both Albinaria s.1. and Herilla belong to the subfamily Alopiinae A.J. Wagner, 1913, V. gulo is the member of the subfamily Baleinae A.J. Wagner, 1913, whereas Pontophaedusa is the member of the taxonomically distant subfamily Phaedusinae (SzEKERES 1999, ZiLCH 1960). In NoRdSIECK's view it constitutes a distinct subfamily (Serrulininae), which, nevertheless, is most closely related to Pheadusinae (NorDSIECK 1999, 2002: 97). Pontophaedusa has N-type CA.

LiKHAREV (1962) showed that uniquely among recent clausiliids juvenile shells of species belonging to the Serrulina-group (e.g. Serrulina serrulata (L. Pfeiffer, 1847)) have columellar lamellae. This determinates that there can be differences between the formation of a serrulinid CA and the closing apparatus of taxonomically distant groups, but the development of a serrulinid CA has not been described yet. It is worth mentioning that juvenile shells of Pontophaedusa funiculum do not have columellar lamellae.

\section{Material and methods}

Observations were made at the University of Patras, Greece.

The animals used in this study were the descendants of ten adult and two juvenile individuals of $P$. funiculum that were collected by the author and L. Németh in Turkey, near the confluence of the Morgul and Çoruh rivers at Borçka, in May, 2006.

To ensure high humidity and proper diurnal illumination cycles, the snails were maintained in translucent plastic boxes filled with wet tissue paper. Snails were kept together in one box (maximum 5 individuals in each box). Visually identified specimens "with eggs" were moved to one of the other boxes until they laid eggs. The juveniles were kept in the third box. The snails were fed primarily with carrot and sliced cucumber, but occasionally also hazelnuts. Shells of helicid snails (e.g. Eobania) and ground shells of chicken eggs served as calcium source. The animals were kept at the room temperature with no heating device in the early spring time. Observations on their reproduction were made daily from February until the end of May. Some other egg-laying periods have also been observed in the summer that is the reason why more batches are present in Fig. 2. than in Table 1. 
In order to describe the details of egg-laying behaviour, 1 to 3-year old specimens have been observed. Unlike those of the older individuals, the shells of younger snails are translucent, which gives a good opportunity to count eggs before being laid out.

From the middle of February until the end of May, six specimens have been observed (specimens 1-6). Four individuals were added in the middle of April (specimens 7-10).

Eight snails with eggs were isolated and kept separately in order to describe their ability to lay eggs without further matings. In order to describe the development of the CA three juvenile specimens have been monitored twice a day while they formed the CA.

\section{Results}

Reproductive biology and life span

The eggs inside the vagina were clearly visible through the shells. Two or three eggs were found there in a linear position in a case, and more eggs were placed in an aslope way in other cases (Fig. 1). In most cases, the eggs which were visible through the translucent shells were laid at once. In only four occasions, they were laid in two parts. The specimen 3 laid three eggs and next day the remaining one egg; the specimen 6 laid two eggs and two days later laid the remainig one egg; the specimen 8 laid five eggs and on the following day the remaining one; the specimen 9 laid three eggs and two days later an additional egg. A total of 213 eggs were obtained in 62 clutches. Clutches consisted of 2-6 eggs (mean 3.44) (Fig. 2). The egg-laying
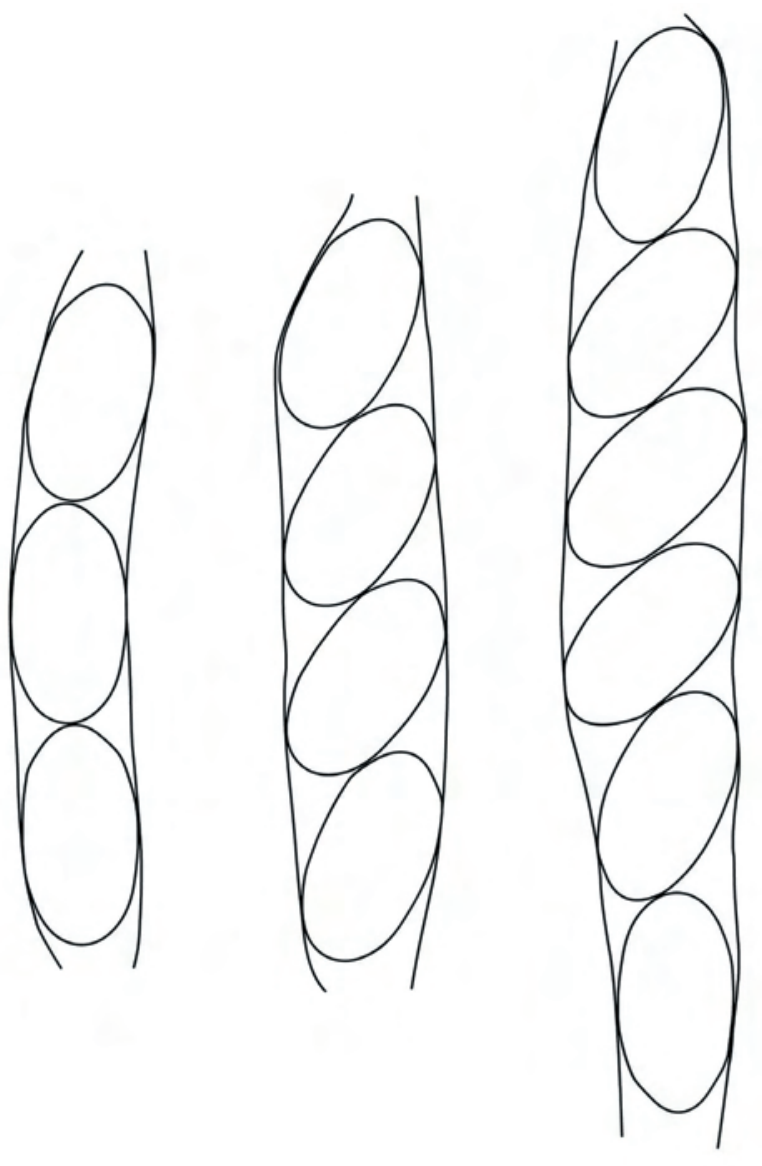

Fig. 1. Position of eggs in the vagina. activity was much lower in the colder days of early spring (specimens 1-6) than in late spring and summer (Table 1). The numbers of laid eggs largely varied among parental individuals. In 38 days (21 April - 30 May), 7-27 eggs (mean: 17) were laid (Table 1).

Egg cannibalism occured sometimes. Adult snails as well as hatchlings were observed eating eggs. They hatched synchronously. After two weeks of isolation of snails with eggs, three out of the eight specimens laid another clutch after their first oviposition.

The present adult specimens collected in Turkey in May 2006 are still living and laying eggs in the present time in 2010. When collected, these adult snails were probably 2-3 years old. Since then, the snails were bred continuously with no period of hibernation. Accordingly, the life span of Pontophaedusa may be longer than 7 years.

Development of the clausilial apparatus

CA formation starts with the lamella inferior (columellaris) and immediately after the lamella spiralis began to form. Strong inferior and spiral lamellae were formed in a day. While these lamellae were becoming stronger, the lamella subcolumellaris, the clausilium and the plica principalis began to form. Two days after the start of the CA formation only the upper lamella (parietalis; which is in contact with the spiral lamella) and the lunella were missing. These formed on about the third day. On the forth day when the clausilium was reaching its final size, the lunella was beginning to form. At the end, the peristome was becoming stronger, but this process (and the formation of small lamellae and teeth on the apertural rim) was continuing for years (see PÁll-Gergely \& Németh 2008, Fig. 5).

\section{Discussion}

Mating behavior

Our previous paper (PÁll-Gergely \& NÉmeth 2008) mistakenly described the mating behaviour of Pontophaedusa funiculum as the face-to-face type. It mates by shell mounting. This type of mating behavior is typical among

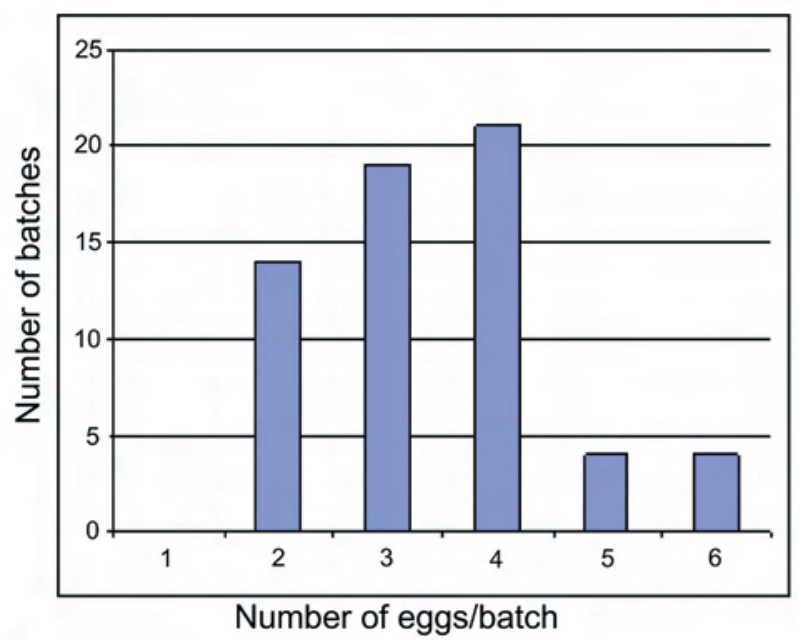

Fig. 2. Distribution of number of eggs per batch. 
Table 1. Fecundity of individuals (number of eggs). Exclamation marks indicate those four clutches which were laid in two parts.

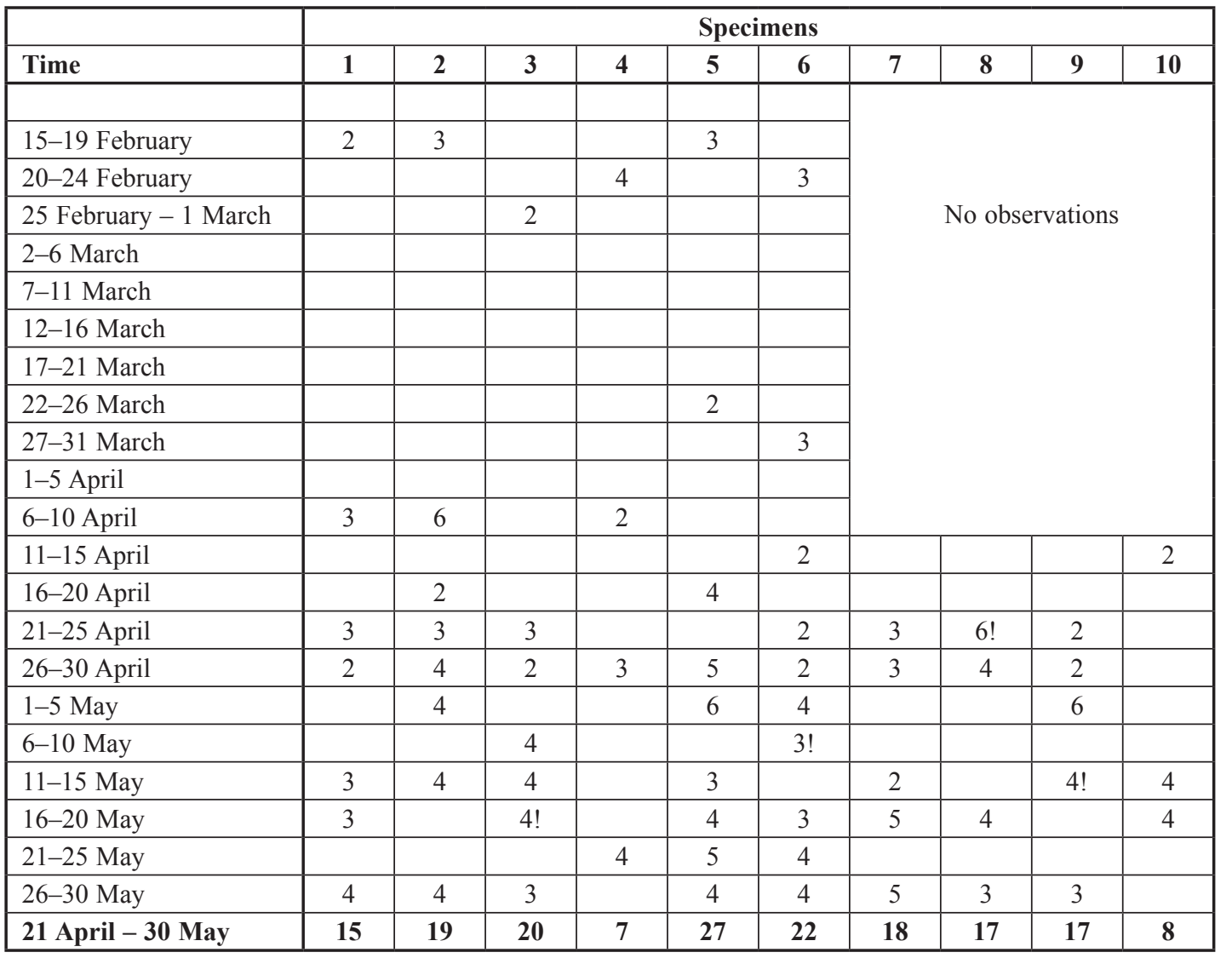

clausiliids. Fig. 3 in our previous paper shows one-way (non-reciprocal) copulation by shell mounting (AsAmi et al. 1998).

Reproductive biology and life span

Pontophaedusa funiculum have never been found laying a clutch of a single egg, as MALTz \& SulikowsKA-DrozD (2008) have reported for nine out of twelve clausiliid species. However, the maximum clutch size in the present study was smaller (six) than the sizes reported for these twelve clausiliid species. The observed maximum in Macrogastra ventricosa (Draparnaud, 1801) was 23, in Vestia gulo (E.A. Bielz, 1859) 19 and in Cochlodina laminata (Montagu, 1803) 17 eggs. The eggs of the present species are two times longer as the eggs of these other species. Thus, the smaller clutch sizes of $P$. funiculum can be mostly probably explaned by a trade-off between the clutch size and egg size.

Individually isolated specimens reproduced because of their ability either to self-fertilize or to store male gametes obtained by previous matings (WIRTH et al. 1997).

It is generally accepted that clausiliids have long lives. The life spans of some clausiliids are the following: Cristataria genezarethana (Tristram, 1865): about 16 years (HELLER \& Dolev 1994), Cochlodina laminata: at least 9 years (Stelfox, 1969), Vestia elata (Rossmässler, 1836): at least 8 years (РIECHOCKI 1982), Balea perversa (Linnaeus, 1758): at least 7 years (WIRTH et al. 1997), species of the genus Albinaria: 7 years (GIOKAS \& MYlOnAs 2002), and Charpentieria ornata (Rossmässler, 1836) and Vestia gulo: at least 6 years (Maltz \& SulikowsKa-Drozd 2009). The life span of Pontophaedusa funiculum is at least 7 years.

Development of the clausilial apparatus

CA is definitely the most complex pulmonate protecting apparatus (see other pulmonate aperture adaptations in GitTENBERGER 1996). It is generally assumed that CA has originated once in the course of evolution (NORDSIECK 1982). EdLAUER (1941) pointed out that CA formation is a sequential process, taking place during the formation of the last whorl of the clausiliid shell. The formation of the lamella and plicae follow a strict order.

Table 2 shows the differences between the CA formation of Herilla (EdLAuer 1941), Albinaria (GitTenberger 2000), Vestia (Sulikowska-Drozd 2009) and Pontophaedusa. In all of the cases CA formation starts with columellaris and ends with "incidential" parts like palatal folds

Table 2. Process of N-type CA formation in Herilla, Albinaria, Pontophaedusa and Vestia. Abbreviations: AF: apertural folds, C: columellaris, CL: clausilium, L: lunella, P: parietalis, PF: palatal folds, PL: principalis, S: spiralis, SC: subcolumellaris.

\begin{tabular}{|l|l|l|l|l|}
\hline & Herilla & Albinaria & Pontophaedusa & Vestia \\
\hline first & C & C & C & C, S \\
\hline & S, P & S, CL & S & P, CL, SC, PL \\
\hline & CL & P & SC, CL, PL & L \\
\hline & SC & SC & P & \\
\hline & PL & PL & L & \\
\hline last & L, PF & PF & AF & AF \\
\hline
\end{tabular}


and teeth of the apertural rim. Among the plicae the plica principalis is the first to form followed by plicae of the lunellar. According to SULIKOWSKA-DROZD (2009), the only difference between the CA formation of Herilla bosniensis and Vestia gulo is the formation of the parietalis. In $V$. gulo this lamella is built significantly later than the lamella spiralis. In Pontophaedusa the formation of the parietalis starts also much later than the formation of the spiralis. In Pontophaedusa the parietalis is formed after the subcolumellaris, whereas in Herilla and in Albinaria the reverse is true. In Vestia subcolumellaris and parietalis are formed at the same time.

The CA has a high taxonomical value and is used for identifying taxa. Some features of the CA can be explained by parallel evolution, and this can be true for the formation of CA. For example, Pontophaedusa and Vestia have fused spiral and upper lamellae which are separated in Albinaria and Herilla. Correct evaluation of the the differences in the CA formation needs more data on different species.

\section{Acknowledgements}

I am grateful to Sinos Giokas (University of Patras, Greece) who has supported my observations in his laboratory, to Aydın Örstan (Carnegie Museum of Natural History, Pittsburgh, USA), to Miklós Szekeres (Szeged, Hungary) and to Takahiro Asami (Shinshu University, Japan) for correcting the English and for their valuable comments and to Richard Preece (University of Cambridge, UK) for sending me Stelfox's paper. I would like to thank three anonymous reviewers for valuable comments on the first version of the manuscript.

\section{References}

Asami T., Cowie R. \& Oybahasi K., 1998: Evolution of mirror images by sexually asymmetric mating behavior in hermaphroditic snails. - The American Naturalist, 152: 225-236.

EdLAUER E., 1941: Die ontogenetische Entwicklung des Vershlussapparates der Clausiliiden, untersucht an Herilla bosniensis. - Zeitschrift für wissenschaftliche Zoologie, 155: $129-158$.

Gittenberger E., 1996: Adaptations of the aperture in terrestrial gastropod-pulmonate shells. - Netherlands Journal of Zoology, 46 (3-4): 191-205.

GitTenberger E., 2000: Alternative pathways in the development of the clausilial apparatus in shells of Albinaria and Isabellaria (Gastropoda: Pulmonata: Clausiliidae). - Basteria, 64 (1-3): 29-32.

Giokas S. \& Mylonas M., 2002: Spatial distribution, density and life history in four Albinaria species (Gastropoda, Pulmonata, Clausiliidae). - Malacologia, 44: 33-46.

Heller J. \& Dolev A., 1994: Biology and population dynamics of a crevice-dwelling landsnail, Cristataria genezarethana (Clausiliidae). - Journal of Molluscan Studies, 60: 33-46.

LiKHAREv I.M., 1962: Fauna SSSR, Molljuski, III, 4 (Clausiliidae)

[Fauna of the USSR, Mollusks, III, 4 (Clausiliidae)]. - Academic Press, Moscow, Leningrad, 317 pp.

Maltz T. \& SulikowsKa-Drozd A., 2008: Life cycles of clausiliids of Poland - knows and unknowns. - Annales Zoologici, 58(4): 857-880.

Nordsieck H., 1982: Die Evolution des Verschlußapparats der Schließmundschnecken (Gastropoda: Clausiliidae). - Archiv für Molluskenkunde, 112 (1/6): 27-43.

NoRdsieck H., 1999: A critical comment on Szekeres' papers concerning Clausiliidae in Basteria 62. - Mitteilungen der Deutschen Malakozoologischen Gesellschaft, 62/63: 23-25.

NordsiECK H., 2002: Annotated check-list of the South East Asian Phedusinae, with the description of new taxa (Gastropoda, Pulmonata, Clausiliidae). - Basteria, 66: 85-100.

PÁll-Gergely B. \& Németh L., 2008: Observations on the breeding habits, shell development, decollation, and reproductive anatomy of Pontophaedusa funiculum (Mousson 1856) (Gastropoda, Pulmonata, Clausiliidae, Phaedusinae). - Malacologia Bohemoslovaca, 7: 11-14.

Piechocki A., 1982: Life cycle and breeding biology of Vestia elata (Rossm.) (Gastropoda, Clausiliidae). - Malacologia, 22: 219-223.

Stelfox A.W., 1969: Marpessa laminata (Montagu) bred in a small box for fifty-four years. - Journal of Conchology, 27: $11-12$.

SulikowsKa-Drozd A., 2009: Development of clausiliar apparatus in Vestia gulo (E.A. Bielz, 1859) (Gastropoda: Pulmonata: Clausiliidae). - Folia Malacologica, 17(2): 77-80.

SzeKeres M., 1999: Remarks on Nordsieck's “A critical comment on Szekeres' papers concering Clausiliidae in Basteria 62, 1998". - Mitteilungen der Deutschen Malakozoologischen Gesellschaft, 64: 17-20.

Wirth T., BAUR A. \& BAUR B., 1997: Mating system and genetic variability in the simultaneously hermaphroditic terrestrial gastropod, Balea perversa on the Baltic island of Öland, Sweden. - Hereditas, 126: 199-209.

ZILCH A., 1960: Euthyneura. - In: Gastropoda, Handbuch der Paläozoologie 6., Wenz W. (ed.) Borntraeger, Berlin, pp. 401600, 601-834. 